NOTE

\title{
Larvae of Contracaecum sp. (Nematoda: Anisakidae) in the threatened freshwater fish Sandelia capensis (Anabantidae) in South Africa
}

\author{
František Moravec ${ }^{1, *}$, Candice Jansen van Rensburg ${ }^{2}$, Liesl L. Van $\mathrm{As}^{2}$ \\ ${ }^{1}$ Institute of Parasitology, Biology Centre of the Czech Academy of Sciences, 37005 České Budějovice, Czech Republic \\ ${ }^{2}$ Department of Zoology and Entomology, University of the Free State, Bloemfontein 9300, South Africa
}

\begin{abstract}
Third-stage larvae of the nematode genus Contracaecum Railliet et Henry, 1912 (Contracaecum sp.) were, for the first time, recorded from the abdominal cavity of the threatened endemic freshwater fish Sandelia capensis (Cuvier) in South Africa. The larval morphology indicated that they belong to a species of which the adults are parasitic in fish-eating birds. Although the nematode seems to be a common parasite of $S$. capensis in the locality under study (prevalence $23 \%$ ), the low intensity of infection recorded (1 to 4 ) and the generally known low pathogenicity of Contracaecum larvae in fish indicate that this parasite probably does not represent a danger to the local population of this threatened fish species.
\end{abstract}

KEY WORDS: Parasitic nematode - Third-stage larva · Paratenic host · Endangered fish species · Africa

Resale or republication not permitted without written consent of the publisher

\section{INTRODUCTION}

Adult nematodes of the genus Contracaecum Railliet et Henry, 1912 are parasitic in the digestive tract of fish-eating birds and marine mammals, whereas their free or encapsulated third-stage larvae are found in the internal organs of fishes serving as paratenic hosts. In Africa, larvae of Contracaecum have frequently been reported as parasites of many $(\sim 70)$ species of freshwater fishes belonging to different families and orders (e.g. Khalil \& Polling 1997 and subsequent authors; see Moravec \& Van As $2015 b)$ and the rate of infection is often very high in some fish hosts. For example, Tavakol et al. (2015) recorded Contracaecum spp. larvae from 9 fish species in the northern regions of South Africa, where prevalence was up to $100 \%$ and mean intensity up to 282 nematodes in Clarias gariepinus (Burchell) from several localities. Contracaecum larvae have not yet been found in African anabantid fishes.
Representatives of the perciform fish family Anabantidae (labyrinth fishes) occur in Africa and southern and south-eastern Asia, including the Philippines and Malay Archipelago. In Africa, the family includes 3 genera (Ctenopoma Peters, Microctenopoma Norris and Sandelia Castelnau) of which 2 species, Ctenopoma multispine Peters and Microctenopoma intermedium (Pellegrin) occur in Botswana, whilst Sandelia capensis (Cuvier) are found at the tip of the African continent and $S$. bainsii Castelnau only in 4 river systems in the Eastern Cape (Skelton 2001). According to FishBase (Froese \& Pauly 2016), the Cape kurper S. capensis is a subtropical freshwater fish (maximum body length $20 \mathrm{~cm}$ ) naturally distributed in the southern and south-western Cape coastal rivers from the Coega River (Algoa Bay) to the Cape Flats and north to Verlorenvlei. Since many populations have declined and are threatened by habitat destruction and predation from introduced bass, this fish is now on The 
IUCN Red List of Threatened Species (Froese \& Pauly 2016).

Five species of trichodinid ectoparasites (3 species of Trichodina Ehrenberg, 1838 and 2 species of Tripartiella Lom, 1959) from C. multispine and $M$. intermedium, and the nematode Camallanus (Zeylanema) ctenopomae Vassiliadès et Petter, 1972 from Ctenopoma sp. were previously reported by Basson \& Van As (2002) and Moravec \& Van As (2015a), respectively, in the Okavango River, Botswana. However, none of the African species of Sandelia was previously studied for the presence of parasites. Therefore, a sample of the threatened endemic fish $S$. capensis collected in South Africa in 1998 was parasitologically examined. Digeneans (metacercariae) recovered were already reported by Jansen van Rensburg et al. (1998); the nematodes of the same material are treated in this paper.

\section{MATERIALS AND METHODS}

In April 1998, 47 specimens of Sandelia capensis (average body length $75 \mathrm{~mm}$ ) from the small stream

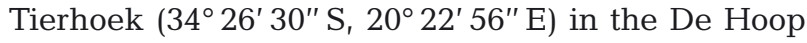
Nature Reserve were examined for the presence of parasites; this stream is a part of the Sout River, which once reached Die Mond (river mouth) but the estuary has been blocked for more than $100 \mathrm{yr}$.

The nematode specimens collected from the viscera of the abdominal cavity of $S$. capensis were fixed in $10 \%$ formalin or $70 \%$ ethanol. For light microscopy examination, these were cleared in glycerine. Specimens used for scanning electron microscopy (SEM) were postfixed in $1 \%$ osmium tetroxide, dehydrated through a graded acetone series, criticalpoint-dried and sputter-coated with gold; they were examined using a JEOL JSM-7401F scanning electron microscope at an accelerating voltage of $4 \mathrm{kV}$ (GB low mode). All measurements are in $\mu \mathrm{m}$ unless otherwise indicated. Voucher specimens were deposited in the Helminthological Collection of the Institute of Parasitology, Biology Centre of the Czech Academy of Sciences, České Budějovice, Czech Republic (Cat. No. N-468).

\section{RESULTS AND DISCUSSION}

The only nematode species found in Sandelia capensis was the third-stage larvae of Contracaecum sp. (prevalence: $23 \%$, intensity: 1 to 4 nematodes per fish).
The bodies of the 10 fixed larvae (Figs. $1 \& 2$ ) are whitish, 28.68 to $36.29 \mathrm{~mm}$ long and 1.27 to $1.51 \mathrm{~mm}$ wide. Transverse striations of cuticle are more distinct on body ends (Figs. 1B-D \& 2A-D). The cephalic end is rounded, bearing a small ventral cuticular tooth 12 to $15 \mu \mathrm{m}$ long and 4 submedian cephalic papillae surrounding the small transverse oval oral aperture; the bases of lips are weakly developed (Figs. 1B,C \& $2 \mathrm{~A}-\mathrm{C})$. The excretory pore is situated below the ventral cephalic tooth. A somewhat elevated region of cephalic papillae is surrounded by several low, circular cuticular lamellae interrupted by lateral lines (Figs. 1C \& 2A-C). The oesophagus is narrow, 3.13 to $3.59 \mathrm{~mm}$ long and 122 to $150 \mu \mathrm{m}$ wide. The ventriculus is small, rounded, 122-136 × 150-218 $\mu \mathrm{m}$ in size; the posterior ventricular appendix is short, 558 to $775 \mu \mathrm{m}$ long and 122 to $177 \mu \mathrm{m}$ wide. The nerve ring is located 340 to $394 \mu \mathrm{m}$ from the anterior extremity. The intestine is brownish. The intestinal caecum is
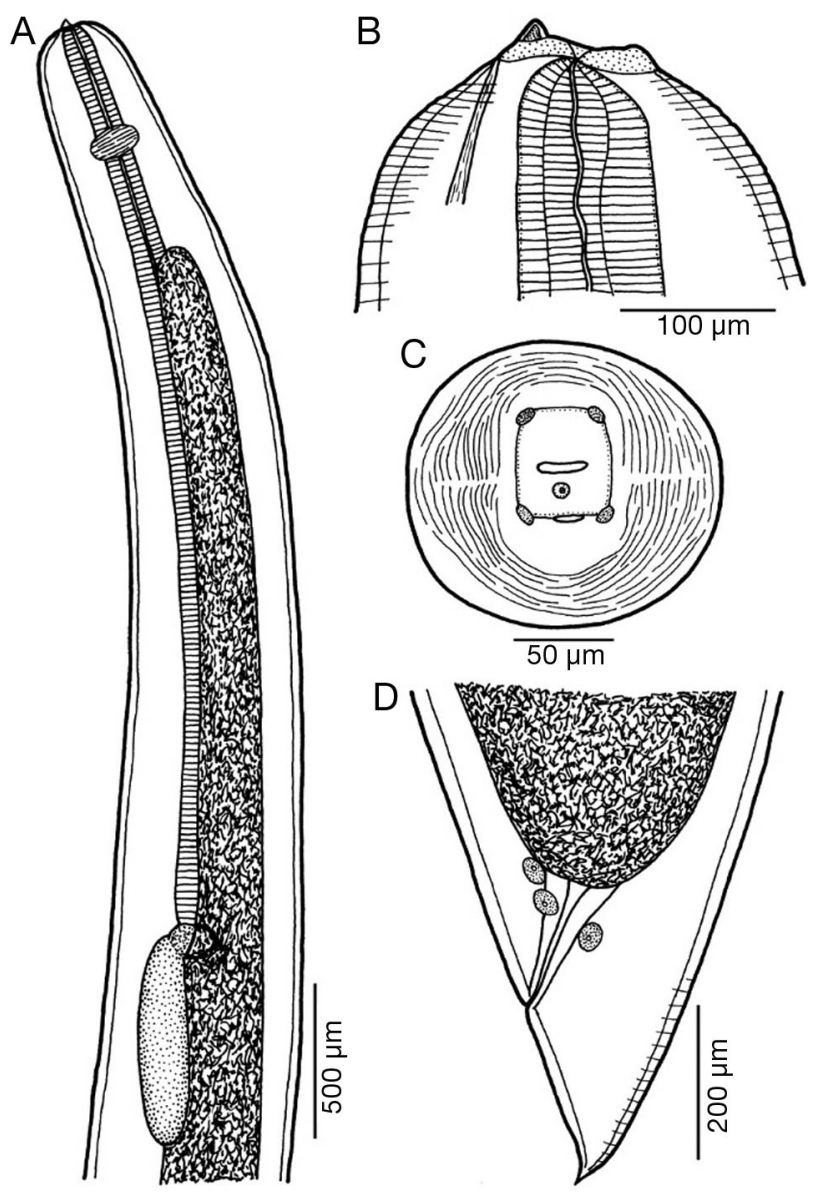

Fig. 1. Contracaecum sp. third-stage larva from Sandelia capensis. (A) Anterior end of body, lateral view; $(B, C)$ cephalic end, lateral and apical views, respectively; (D) tail, lateral view 

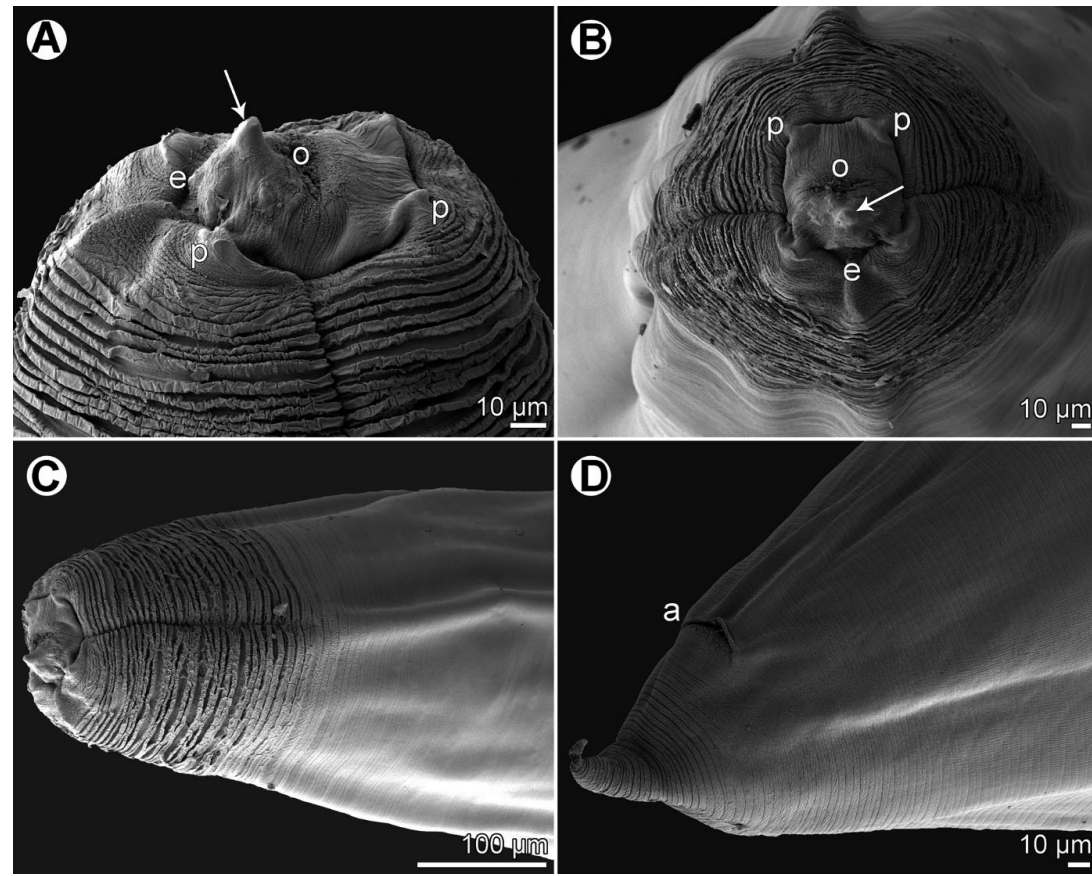

Fig. 2. Contracaecum sp. third-stage larva from Sandelia capensis, scanning electron micrographs. $(\mathrm{A}, \mathrm{B})$ Cephalic end, sublateral and apical views, respectively (arrow indicates ventral boring tooth); (C) anterior end of body, lateral view; (D) caudal end, sublateral view. a: anus; e: excretory pore; o: oral aperture; p: submedian cephalic papilla

very long, extending anteriorly almost to the nerve ring; its length is 2.36 to $2.94 \mathrm{~mm}$, maximum width 245 to $299 \mu \mathrm{m}$ (Fig. 1A). The length ratio of the caecum and ventricular appendix is $1: 0.2-0.3$. The genital primordium is indistinct. The rectum is a short hyaline tube; 3 small unicellular rectal glands are present. The tail is conical, 122 to $258 \mu \mathrm{m}$ long, ending in a sharp cuticular spike (Figs. 1D \& 2D).

These larvae from $S$. capensis are characterized by the presence of a conspicuously long intestinal caecum reaching anteriorly nearly to the nerve ring and a markedly short ventricular appendix. Larvae with this morphology were designated as Contracaecum Type 2 by Moravec et al. (1993); these may belong to the morphological group of several species of this genus parasitizing mainly fish-eating birds as adults. In Africa, similar larvae of Contracaecum sp. were reported by Barson \& Avenant-Oldewage (2006) from the catfish Clarias gariepinus (Burchell) in South Africa, and by Moravec \& Van As (2015b) from 6 fish species of the families Alestidae, Cichlidae and Clariidae in Botswana. As visible from SEM micrographs of the cephalic end (Fig. 2A-C), the larvae from $S$. capensis differ slightly from those reported by the latter authors in that the cuticular lamellae surrounding the elevated cephalic region are inter- rupted by very narrow lateral lines instead of fairly wide smooth lateral fields.

However, the species identification of Contracaecum larvae from fishes based on morphological features is practically impossible. The life cycles of many Contracaecum species have not yet been studied and, consequently, the systematics of Contracaecum larvae from fishes is so far little known. The species of Contracaecum are described from adults found in definitive hosts (e.g. fish-eating birds), so it is impossible to assign congeneric larvae from naturally infected fishes to any species without carrying out feeding experiments or using molecular methods (Moravec 2013).

Barson \& Marshall (2004) recorded 4 adult species of Contracaecum-C. carlislei Ortlepp, 1938, C. microcephalum (Rudolphi, 1819), C. rudolphii Hartwich, 1964 and C. tricuspis (Gedoelst, 1916) - from piscivorous birds in Zimbabwe, mentioning that all of them were previously reported from South Africa. Of these, the third-stage larvae of C. rudolphii obtained from experimentally infected fish (common carp) attained the maximum body length $(<5 \mathrm{~mm}$ ) after 18 mo post-infection (Moravec 2009), whereas the larvae from African fishes reported by Moravec \& Van As (2015b) and those of the present material from $S$. capensis were approximately 4 to 7 times longer and their morphology was different; this indicates that the above-mentioned larvae from African fishes did not belong to C. rudolphii, a common parasite mainly of cormorants.

Although some authors (e.g. Tavakol et al. 2015) still consider copepods and fishes to be the first and second intermediate hosts, respectively, of Contracaecum spp., the available data show that the thirdstage larvae of these nematodes develop already inside eggs in the external environment (water) and are already infective for the definitive host (Thomas 1937, Køie \& Fagerholm 1993, 1995, DziekońskaRynko \& Rokicki 2007, Moravec 2009). However, a variety of invertebrate (copepods, larvae of aquatic insects) and vertebrate (fish, less often amphibians and reptiles) paratenic hosts usually participate in the transmission of Contracaecum species to the definitive host (Moravec 2009). 
The recorded prevalence (23\%) of Contracaecum sp. larvae in $S$. capensis indicates that these parasites commonly occur in this host species in the locality under study. However, neither encapsulated nor free Contracaecum larvae are known to severely affect fish (even multiple infection has no apparent impact of the body condition). Therefore, in view of a low intensity of infection recorded in $S$. capensis, this parasite does not seem to endanger the local population of this threatened fish species. The Cape kurper $S$. capensis represents a new host record for Contracaecum sp. larvae.

Acknowledgements. The authors thank staff at De Hoop Nature Reserve and Cape Nature South Africa, for assistance during fieldwork. Thanks are also due to the staff of the Laboratory of Electron Microscopy, Institute of Parasitology, Biology Centre of the AS CR, České Budějovice for their technical assistance, and to Blanka Škoríková of the same Institute for help with illustrations. This study was partly supported by the Czech Science Foundation (grant no. P505/12/G112) and the Institute of Parasitology, BC AS CR (institutional support RVO:60077344).

\section{LITERATURE CITED}

Barson M, Avenant-Oldewage A (2006) Nematode parasites of Clarias gariepinus (Burchell, 1822) from the Rietvlei Dam, South Africa. Onderstepoort J Vet Res 73:87-94

Barson M, Marshall BE (2004) First record of Contracaecum spp. (Nematoda: Anisakidae) in fish-eating birds from Zimbabwe. J S Afr Vet Assoc 75:74-78

Basson L, Van As JG (2002) Trichodinid ectoparasites (Ciliophora: Peritrichia) of freshwater fishes of the family Anabantidae from the Okavango River and Delta (Botswana). Folia Parasitol 49:169-181

Dziekońska-Rynko J, Rokicki J (2007) Experimental infestation of copepods and amphipods with Contracaecum

Editorial responsibility: Stephen Feist, Weymouth, UK rudolphii larvae. Proc IV All-Russian Workshop Theor Mar Parasitol, AtlantNIRO Publishing, Kaliningrad, p 58-60

Froese R, Pauly D (eds) (2016) FishBase. www.fishbase.org (accessed 20 March 2016)

Jansen van Rensburg C, Basson L, Van As JG (1998) Metacercarial trematodes associated with Sandelia capensis Cuvier, 1831. Microsc Soc S Afr 28:80

Khalil LF, Polling L (1997) Check list of the helminth parasites of African freshwater fishes, 2nd edn. University of the North, Pietersburg

Køie M, Fagerholm HP (1993) Third-stage larvae emerge from eggs of Contracaecum osculatum (Nematoda, Anisakidae). J Parasitol 79:777-780

$>$ Køie M, Fagerholm HP (1995) The life cycle of Contracaecum osculatum (Rudolphi, 1802) sensu stricto (Nematoda, Ascaridoidea, Anisakidae) in view of experimental infections. Parasitol Res 81:481-489

Moravec F (2009) Experimental studies on the development of Contracaecum rudolphii (Nematoda: Anisakidae) in copepod and fish paratenic hosts. Folia Parasitol 56:185-193

Moravec F (2013) Parasitic nematodes of freshwater fishes of Europe, revised $2^{\text {nd }}$ edn. Academia, Prague

$>$ Moravec F, Van As LL (2015a) Studies on some spirurids (Nematoda: Spirurida) from fishes of the Okavango River, Botswana. Syst Parasitol 91:119-138

> Moravec F, Van As LL (2015b) Studies on ascaridid, oxyurid and enoplid nematodes (Nematoda) from fishes of the Okavango River, Botswana. Folia Parasitol 62:039

Moravec F, Kohn A, Fernandes BMM (1993) Nematode parasites of fishes of the Paraná River, Brazil. Part 2. Seuratoidea, Ascaridoidea, Habronematoidea and Acuarioidea. Folia Parasitol 40:115-134

Skelton P (2001) A complete guide to the freshwater fishes of Southern Africa. Struik, Cape Town

Tavakol S, Smit WJ, Sara JR, Halajian A, Luus-Powell WJ (2015) Distribution of Contracaecum (Nematoda: Anisakidae) larvae in freshwater fish from the northern regions of South Africa. Afr Zool 50:133-139

Thomas LJ (1937) On the life cycle of Contracaecum spiculigerum (Rud.). J Parasitol 23:429-431

Submitted: April 11, 2016; Accepted: June 15, 2016

Proofs received from author(s): August 4, 2016 